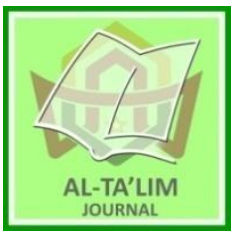

AL-TA'LIM JOURNAL, 26 (2), 2019, (160-174)

(Print ISSN 1410-7546 Online ISSN 2355-7893)

Available online at http://journal.tarbiyahiainib.ac.id/index.php/attalim

\title{
The Urgency of Holistic Education in Muhammadiyah Schools
}

Received: 31 $1^{\text {th }}$ January 2019; Revised: 28 $8^{\text {th }}$ June 2019; Accepted: $31^{\text {th }}$ July 2019

Permalink/DOI: http://dx.doi.org/10.15548/jt.v26i2.549

\section{Hendro Widodo *)}

Universitas Ahmad Dahlan Yogyakarta, Indonesia.

E-mail: hwmpaiuad@gmail.com

\section{Sutrisno}

Universitas Islam Negeri Sunan Kalijaga

Yogyakarta, Indonesia.

E-mail: risno63@gmail.com

\section{Farida Hanum}

Universitas Negeri Yogyakarta, Indonesia. E-mail: faridapane@ rocketmail.com

\begin{abstract}
This article focuses on the importance of implementing holistic education in Muhammadiyah schools. The essence of education is to develop the full potentials of humanity covering the potentials of cognitive, emotional, social, spiritual, creativity, and physical. The six potential humanities are a unity, which means a potential can be developed through another potential. Partial views of teachers on the potential of students have implications for non-intact practice of education in schools that make split personality on students. Muhammadiyah education as a part of the national education system is the mandate of the constitution to produce holistic man through education in Muhammadiyah schools. This article is based on research results at Muhammadyah Sleman Yogyakarta Elementary School.
\end{abstract}

\section{*) Corresponding Author}

Keywords: Holistic education; Muhammadiyah schools; urgencys.

How to Cite: Widodo, H., Sutrisno, S., \& Hanum, F. (2019). The urgency of holistic education in Muhammadiyah schools. Al-Ta Lim ournal, 26(2). doi:http://dx.doi.org/10.15548/jt.v26i2.549

\section{INTRODUCTION}

Muhammadiyah education as a part of the national education system is the mandate of the constitution to produce holistic man through education in Muhammadiyah schools (Fuad, 2004; Jackson \& Parker, 2008). Gunawan Suryoputro, Pudjo Sumedi, \& Muchdie (2014); Suprayogo (2012) assert that Muhammadiyah educational institutions have developed rapidly, both basic and intermediate level, even universities spread all over the country. The style of schools or educational institutions of Muhammadiyah provides benefits for Indonesian in terms of educating the life of the nation.

This is proven by the Muhammadiyah's work in the field of education where the existence of
Muhammadiyah education institutions is larger. In 2010, Muhammadiyah has 4,623 Kidergartens, 6,723 Early Childhood Education institutions; 15 Special Schools; 1,137 Elementary Schools; 1,079 Madrasah Ibtidaiyah; 347 Madarasah Diniyah; 1,178 Junior High School; 507 Madrasah Tsanawiyah; 158 Madrasah Aliyah; 589 High School; 396 Vocational High School; 7 Muallimin / Muallimat; 101 Islamic Boarding Schools (Pondok Pesantren); and 3 Secondary Schools of Pharmacy (Nakamura, 2012).

One of the prominent features of Muhammadiyah educational institutions is the ones that present the values of renewal in our education practice as it is according to the characteristic of the parent organization, namely Persyarikatan Muhammadiyah. It is 
called bringing renewal because the educational institution established by $\mathrm{KH}$. Ahmad Dahlan has a different style with the existing educational institutions or schools, namely by establishing schools that adopt the form of Western model schools by combining it with Islamic values. The combination of these two educational cultures is known as "School Met de Quran". The Dutch term is defined as a school with the values of Qur'an (Burhani, 2005).

Schools with the values of the Qur'an is a form of modernization of Muhammadiyah education towards Dutch schools. One of the educational modernization agendas that Ahmad Dahlan prescribed from the beginning was the curriculum reform. This reform agenda was urged because at that time he saw the dualism of education. On the one hand, Dutch schools taught only general sciences. This policy was seen to keep students from faith and piety. On the other hand, the traditional Islamic education, which was represented by Islamic boarding schools (pesantren), only taught religious knowledge and ignored general knowledge which was very beneficial for the development of Muslim civilization. In such a context, Ahmad Dahlan seemed to realize how the duality of education will only give birth to a generation with a split personality. Students studying at a Dutch school will be a person who thought only of worldly interests. Meanwhile, the generation of Muslims studying in Islamic boarding schools (pesantren) was only oriented toward the afterlife (Setiawan, 2015).

In the midst of such situation, Ahmad Dahlan believed that the dynamics of change that had been, was or would happen could be anticipated by teaching the sciences of religion and general sciences in an integrated one (holistic). This belief was then applied in the Muhammadiyah schools. Therefore, the integration of religious and general knowledge in the curriculum is one of the characteristics of Muhammadiyah education. This modern curriculum later became a distinction between Muhammadiyah schools and other educational institutions. This characteristic was first established by Ahmad Dahlan when establishing a modern educational institution in Kauman on December 1. Thus, since the beginning of establishment, the modern educational institution has a characteristic in which the curriculum combines religious and public lessons (Susilo, 2017).

Therefore, the formulation of Muhammadiyah educational philosophy states that Muhammadiyah education is a modern Islamic education that integrates religion with holistic life, faith, and progress. From that original state of Islamic education, then it forms a generation of educated Muslims who are strong in faith and personality, as well as able to face and answer the challenges of the times. This is what is called by the progressed Islamic education (Amirudin, 2018; Huda \& Kartanegara, 2015).

From the description above, it illustrates that Muhammadiyah education emphasizes the unity, both the education system and practice, as well as the goals to be achieved by education. K.H. Ahmad Dahlan called this whole education as an education that balances between mental and physical development, between belief and intellect, between feeling and mind, and between the world and the afterlife (Santosa, 2012).

This balanced education represents the unity and integration where its focus is not on one aspect. Ali (2016) affirms the educational objectives of K.H. Ahmad Dahlan can be formulated into three key concepts, namely individual education, moral education or morals, and social education. The formulation of educational objectives by K.H. Ahmad Dahlan shows the trident of educational objectives which are individual, moral, and social growth that is similar to the concept of holistic education. It means that the trident of educational objectives by KH. Ahmad Dahlan is a form of educational holistic goals.

Therefore, since the beginning before the existence of the National Education System, Muhammadiyah education has 
oriented to the development of humanitarian potential that carries the holistic education mission, which is expected to form students who are not only intelligent from the intellectual side but also who can develop other humanitarian potential. Those are emotional, physical, social, aesthetic, and spiritual as they can be better in implementing the principles of religion in everyday life. It is also reinforced by the 46th and 47th Muhammadiyah Congress results, which formally makes the holistic Muhammadiyah education as the vision of Muhammadiyah education program development.

Muhammadiyah schools as a part of the national education system are being dragged into the practice of the national education system. The quality condition of Muhammadiyah schools is increasingly concerning because the leaders, cadres and school managers of Muhammadiyah are not able to hold the vision of Muhammadiyah schools which is holistic-transformative as stated above. Muhammadiyah schools are swept away in an effort to hold their identity. In addition, the current standardization of education embodied in the National Examination (UN) has made Muhammadiyah schools become more superficial. The practice of the UN in Indonesia has led to a tremendous superficial education. What the schools do is only for one goal, to be specific the students pass the UN. Thus, all the power, energy, thought and school activities are just the efforts to deliver students to pass the UN. The schools consider other things as unimportant characters and things never thought of. In other words, the implementation of the UN has made education happen without spirit and conscience (Syaifuddin, Anggraeni, Khotimah, \& Mahfud, 2019). Such educational practices can distort the nature of education itself.

According to Hamami (2011), the phenomena and educational problems mentioned above, occur because schools are trapped in the developmental currents of education which is based on the positivistic thinking making them lose their idealism consciously or unconsciously. Hamami (2011) adds that in reality, there is still a gap in Muhammadiyah's educational outcomes with the expectations. Many of the graduates of Muhamamdiyah schools have the Islamic religious knowledge but they have not reflected in daily life.

Susilo (2017) identify the Muhammadiyah educational problems, regarding to the absence of Islamic values in the behaviour of the school citizens, and inability to create a representative Islamic culture, losing their identity, and even some of the Muhammadiyah schools almost have no difference from other schools.

The problem is an academic problem that needs to be criticized and solved by educational institutions, especially in this case Muhammadiyah schools. Muhammadiyah education needs to transform that students' achievement that will be realized are not only the academic achievement, but also as an intact, which includes academic quality, moral toughness and social sensitivity. To realize the figure of this intact student, the theory and reality should not be separated. Students learn something simultaneously integrated between the theories and reality of life, from books and from society. In addition, between formal and non-formal programs are bridged which are embodied in various activities of Muhammadiyah autonomous organizations, especially Hizbul Wathan, Muhammadiyah Student Association, and Tapak Suci (Nuryana, 2017)

The reality of the educational process proves that holistic education in Indonesia is increasingly important to fight for its actualization and should not just be a trend. This is supported by Widyastono's research results (2012) which conclude that holistic education has not been implemented comprehensively in learning. The learning has only developed the realm of knowledge, but has not developed the realm of students' skills and affective affairs. 
However, the main idea of education lies in the view that every human being has a positive value about intelligence, creativity, and nobility. The role of education is how those positive values can grow strong, so there is some improvement in everyone's personality to be smart, creative, and virtuous. If the education is improper, students' personalities can grow negative; violent, ignorance, or create other crimes (Ahmad, 2015; Mawardi, 2016). If the negative nature as a result of the non-intact positive value is developed in education, then it can cause a split personality on students.

Muhammadiyah schools as a part of the National Education System as well as the Islamic Education has mandated the implementation of holistic education. This means that all Muhammadiyah educational institutions carry the mission of implementing holistic education, which is an educational model that develops all humanitarian potential aspects of the learners (cognitive, emotional, social, spiritual, creativity, and physical). Then, it is expected to produce holistic students who are not only intelligent in cognitive-intellectual side, but also who can develop other humanitarian potential.

\section{METHOD}

This research was conducted at Muhammadiyah Sleman Elementary School Yogyakarta, Indonesia. This research combined theoretical and empirical research. This research was qualitative research. The paradigm in this research was interpretive paradigm, looking at social reality as something holistic/intact, complex, dynamic, full of meaning, and the relationship of symptoms was interactive/reciprocal. While the research approach was phenomenology, where researchers were involved in the situation and settings of the phenomena being researched. Data collection techniques were observation, in-depth interviews, and documentation. Data analysis was by interactive model of data collection, data reduction, data presentation, and conclusion or verification (Mihas, 2019)

\section{RESULT AND DISCUSSION}

\section{Holistic Education}

Holistic terminology in the Qur'an can be represented by the term kaffah. This term is written in the Qur'an:

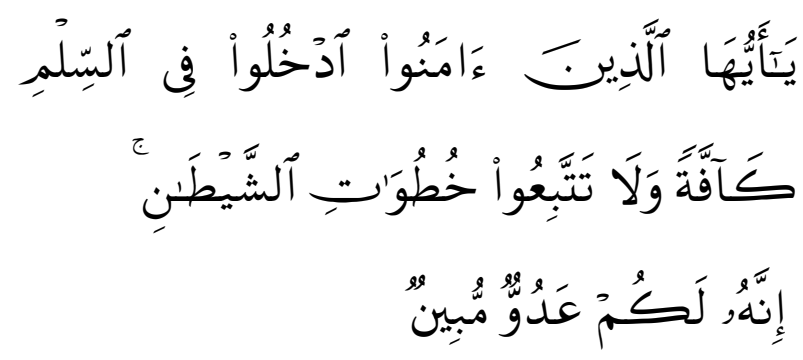

Translation:

"O you who have believed, enter into Islam completely [and perfectly] and do not follow the footsteps of Satan. Indeed, he is to you a clear enemy. (QS. Al-Baqarah: 208).

The above verse confirms Muslims to Islam as a whole (Islam Kaffah). Islam Kaffah contains the meaning of total submission to all the commands of Allah that are formulated in the Qur'an and Hadith. The Qur'an and the Hadith are the main sources of Islamic law governing all matters of human life in the world (Mulkhan, 2010)

According to Wahyudi (2006), the concept of kaffah Muslim is a blend of human submission to the three verses of God, namely: the Qur'aniah, Kauniah, and Insaniah verses. First, the Qur'aniah (Qauliah) verse is the rules summarized in the Qur'an and al-Hadith. The people who obey the Qur'aniah verse are called theological Muslims. Second, the Kauniah verse is the signs of God's greatness in the universe (the cosmos). Sunnatullah or God's destiny (natural law) holds a key role in determining safety or peace in the world. Third, the Insanah verse is the signs of greatness or the laws of Allah governing human life (cosmic). The most important law here is the law of spouse. Islam and Faith (safe and secure) at this level is to balance the positive and negative potentials which create a balance or social justice (Amin, 2017; Chaidar \& 
Sahrasad, 2013; Murod, 2011). Allah has delegated this balance law to the mankind as reflected in the Hadith "The pleas of Allah depends on the pleases of man (parents)".

A Muslim who is kaffah means that his whole life is submissive and obedient to the rules of Islam. The attitude and behaviour of his life is in accordance with the guidance of Islam as exemplified by the Prophet Muhammad SAW. The attitude and behaviour that are in accordance with the guidance of Islam are also called as religious morals (Lubis \& Zubaedi, 2008).

The Qur'an also asserts that humans as individuals have been created in the best form. This is as mentioned in QS. At-Tin: 4.

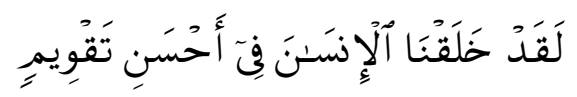

"We have certainly created man in the best of stature."

According to Ibn Thufail, the best of stature are the three fundamental aspects of education which are the cognitive domain (al'aqliyyah), affective (al-khuluqiyyah alruhaniyyah), as well as psychomotor (al'amaliyyah). All three are the main requirements for the achievement of the educational goal of is to realize a whole mankind by combining natural knowledge through discursive research and knowledge of religion based on revelation through the Prophets and Messenger of Islam. Thus it produces a figure who are capable of balancing vertical life and horizontal life (Masruri, 2009).

Another definition of holistic education proposed by Muslim scholars at the First World Conference about Islamic Education states that education should aim to achieve a thoroughly balanced growth of the human personality through the practice of the soul, the intellect, the rational human person, the feeling, and the senses. Therefore, education must reach human growth in all its aspects: spiritual, intellectual, imaginative, physical, scientific, language, individually or collectively, and push all these aspects toward goodness to achieve perfection. The ultimate goal of Muslim education lies in the manifestation of the perfect submission to Allah both personally, community, and all humanity (Surajudeen, Mat, \& Alizadegani, 2017).

Embong et al., (2015); Hassan, Suhid, Abiddin, Ismail, \& Hussin, (2010) interprets holistic education as of perfect Muslims which are as follows:

a. Physically healthy and strong, with some characteristics: healthy, strong, and skilled.

b. Intelligent and smart, with some characteristics: 1) Able to solve problems quickly and accurately; 2) Able to solve problems scientifically and philosophically; 3) Own and develop science; 4) Own and develop philosophy.

c. His heart is piety to Allah, with some characteristics: 1) volunteering to carry out Allah's commands and stay away from His prohibitions; and 2) a capable heart associated with the occult.

If it is simplified, Islamic education has one main goal which is the realization of perfect Muslim figures. This education is called holistic education. According to Biesta (2009) good education is an education in which the process is able to develop all the nature of learners, especially the nature of sense and religion. With those natures, learners can develop thinking ability in a rational way. While through the nature of religion, the pillars of goodness are embedded within the students which then implicated in all activities of their life.

In this context, the main task of a religious education in the perspective of Islam is to create perfect personality figures (insan kamil). Thus, according to Al-Syaibani, the implementation of Islamic education should be more emphasize on the aspects of religion and morals and not only the intellectualrational aspect. The emphasis is holistic and it pay attention to the full potential of the learners which includes the intellectual, psychological, social, and spiritual potential in a balanced manner with other sciences (art, 
physical education, military, engineering, foreign languages, etc.) and it is accordance with the dynamics of the current development and the needs of the society in which the education is conducted (Mundiri, 2016)

Azra (2002) refers holistically to the term "Tauhid Paradigm", which means not only believing in oneness of God but also integrating all aspects, all the views and aspects of life within the system and the field of social life. This means in the context of education there must be in harmony, unity, or law with more emphasis on the spiritual aspect, namely the mental aspects. This view shows that holistic education requires a comprehensive integration between the intellect and the faith aspect, heart-cantered mind and then the aspect of charity, namely the activity (motor).

Holistic education is an education that develops learners' potentials harmoniously (integrated and balanced), including the intellectual, emotional, physical, social, aesthetic, and spiritual (Miller, Karsten, Denton, Orr, \& Kates, 2005). These six aspects should be harmoniously developed. All dimensions of child's development occur simultaneously and integrated as each of them do not stand alone and the development of every of the aspect is influenced by other aspects.

Thinkers and classical scholars from Swiss Pestalozzi view three aspects of education as intellectual, moral, and physical that must be developed into a holistic or whole and harmonious to be able to build a balanced and strong child's personality. Pestalozzi views moral education as the most important thing, because without moral education, the development of other aspects (intellectual and physical) will lose their ways. Pestalozzi in M.R. Heafford (2016), it is said: "Yet, Pestalozzi regarded moral education as being most important, for without it, the other type would lose their sense of direction."

In Pestalozzi's view, moral education is the most important goal of education, where intellectual and physical education are the subordinates (lower) to moral education. It is as if the intellectual and physical educations beyond its own aspect is for moral development. The purpose of outdoor physical education is aimed to train students' physical or physical health is to develop morality that develop the learning motivation, determination and courage, honesty and sportive in doing the work.

As Pestalozzi's view, as there is some interrelationship among the aspects of cognitive, moral, and physical education, it is said that one aspect can be developed through other aspects. In line with Pestalozzi, Citing Kessler, Schiller believes as quoted in Miller (2005) who says that ... "learning cannot be separated into cognitive, psychological, physiological, or spiritual." Therefore, cognitive, affective (psychological), motor (physiological), or religious (spiritual) aspect is a unity in a learning.

Holistic education is an education that develops all learners' potential harmoniously (integrated and balanced), including intellectual, emotional, physical, social, aesthetic, and spiritual (Miller, 2005). These six aspects should be harmoniously developed. All dimensions of children's development occur simultaneously and integrated, each not stand alone and the development of one aspect is influenced by other aspects. Nava (2000) described a holistic education model that has multidimensional potential, including intellectual, social, emotional, physical, aesthetic, and spiritual, as illustrated in the following figure:

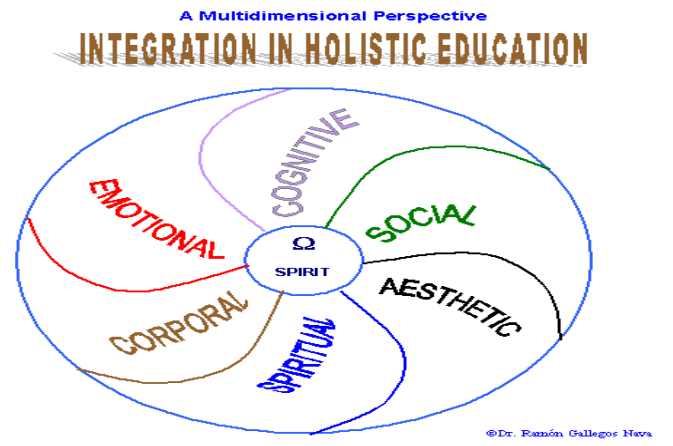

Figure 1. Multi-Dimensional Perspective Integration in Holistic Education (Nava, 2000) 
Thus, it can be concluded that holistic education is an educational model that builds human beings fully and balanced by developing all potentials including cognitive/academic, emotional, social, spiritual, creativity, and physical potentials.

\section{Holistic Education in Muhammadiyah Schools}

Referring to the conceptualization of holistic education discussed above, as a matter of fact since the beginning of Muhammadiyah schools, the founder, $\mathrm{KH}$ Ahmad Dahlan had emphasized on the integrity, both system and practice of education, as well as goals that will be generated by the education. Palahuddin (2018) asserts that the formulation of educational objectives of KH. Ahmad Dahlan is to produce a religious man whose entire personal potentials (individuality) can grow unanimously, possess high morals, and have a positive social attitude manifested in the form of social actions to promote the life and prosperity of society. This concept also confirms that in Muhammadiyah education, the two sides of the basic needs of human life, material and spiritual needs are seeking to be harmoniously developed (Kuntoro, 2006).

Zamroni (2014) asserts that the wholeness (holisticness) of education is meant to have a transformative nature, namely the education that will lead people's lives toward spiritually and materially better. Moreover, Zamroni clarifies the holistic and transformative educational system and practice established by K.H. Ahmad Dahlan has characteristics, including: 1) wholeness in objectives and learning materials, 2) the integrity of theory and practice, 3) the integrality between formal and non-formal education, and 4) the unity among various educational centres.

Zamroni (2010) observes from the socio-anthropological side by emphasizing on the profile of educational graduates idealized by Muhammadiyah education. The observation from this sociological view,
Zamroni named the education praxis by Kyai Dahlan as a transformative holistic education. It is called as a holistic education because the goal of Muhammadiyah education is to produce a complete human being. This is in line with the popular short slogan at that time, which said: "intellectual-theologian, intellect theologian". The process of education is a blend of theory and reality (practice), with a short slogan: "science of alms, scientific alms". At last, to encourage and motivate learners to master what is learned thoroughly with the motto: "we reap what we sow".

Kyai Dahlan's educational thinking is called transformative education because Muhammadiyah's educational goals are not only to provide supplies that can be applied in various conditions, but also must be able to transform (transform) themselves and society. Thus, Muhammadiyah's education encourages the students to not only mastering the knowledge and technology being taught, but also willing to internalize the knowledge they learn into their hearts so that there is a process of self-transformation, and willing to share with the community at the same time.

Referring to the explanation above, the concept of transformative holistic education is intended to mention educational praxis that aims to produce and educate learners into a complete intact person who is characterized by the optimal growth of all potentials. The optimization of self-potential is not to produce a selfish individual who only takes care of his own affairs, but also becomes a social-minded person who is willing to be involved in improving his society. With such understanding, Zamroni emphasizes Kyai Dahlan's education praxis on the wholeness of the graduates' profile can be done where there is some social interaction with the surrounding community.

K.H. Ahmad Dahlan called this whole education an education that balances mental and physical development, between belief and intellect, between feeling and mind, and between the world and the afterlife (Mason, 2008). Noddings (2018) asserts that the educational objectives of K.H. Ahmad Dahlan 
can be formulated into three key concepts, namely individual education, moral education or morals, and social education.

The formulation of educational objectives by K.H. Ahmad Dahlan shows the trident of educational objectives of individual, moral and social growth that is similar to the concept of holistic education. It means that the trident of educational objectives by $\mathrm{KH}$. Ahmad Dahlan is a form of educational holistic goals.

Kuntoro and Astuti (2012) describe the characteristics of Muhammadiyah schools and educational system or the foundational thinking of education by K.H. Ahmad Dahlan as follows: 1) the educational foundation is based on religion as religion cannot be separated from life; 2) the education in schools teaches religion and general science simultaneously; 3) an appreciation of intellectual intelligence as the modal to develop a dynamic life and renew the religious practice and thinking that impede the progress; 4) religion is dynamically understood, not merely a ritual activity but it is practiced to improve the life of the community, and 5) the purpose of education is to build noble characters committed in the effort to improve and promote social life.

Kuntoro and Astuti's opinion shows that the orientation of Muhammadiyah education is on the development of intellectual intelligence, noble characters and social life. The three elements are a unity, integrated in Muhammadiyah school system. Therefore, it can be emphasized that Muhammadiyah education or foundational thinking of education by K.H. Ahmad Dahlan has oriented towards the development of humanitarian potentials since from the very beginning (holistic education).

Amirudin (2018); Kim (2010) mentions and names the educational praxis by K.H. Ahmad Dahlan as a humanitarian education. This naming refers to the educational objectives outlined by K.H. Ahmad Dahlan. According to Abdul Munir Mulkhan's interpretation, the purpose of education in view of K.H. Ahmad Dahlan is the formation of an independent social unit for saving the world as the realization of Islamic teachings in the life of society and nation in the midst of the association of the world. Mulkhan adds the activities and education praxis by K.H. Ahmad Dahlan was aimed to design a new world, and a unity of humanity in the advancement of science and technology as well as the civilization that is based on the ethics in the Qur'an.

Actually, every learner has human potentials namely cognitive, emotional, social, spiritual, creativity, and physical potentials. However, those potentials can develop better through education. The educational process is the one that can develop the potentials to be more optimal. The holistic education process is viewed that capable to develop the potentials because in the view of holistic education, the potentials are a unified entity that can develop to build a balanced and strong childhood personality.

\section{Curriculum of Holistic Education in Muhammadiyah Schools}

Holistic education in Muhamadiyah schools is presented in the national curriculum and Muhammadiyah curriculum. This is in line with the Decision of the Muhammadiyah Central Executive Council of Education and Teaching Assembly No: E.1/183/1976 on the Guidelines for the Implementation of Qaidah of Muhammadiyah Primary and Secondary Schools Chapter VII article 10 which states that as long as there is no other regulation, the curriculum applied in regular schools also works for Muhammadiyah schools. In addition, there is also a special curriculum established by Muhammadiyah.

The curriculum is the soul and guidance in the education practice in the schools. The descriptions of the qualifications that are expected to be attached to each of the school graduates will be reflected in the curriculum which is designed by the school manager. The designed curriculum should 
contain the grand design of holistic education, whether in the form of a formal curriculum or a hidden curriculum. The designed curriculum should reflect the vision, mission and goals of the school that has committed to holistic education.

Being an excellent school with holistic values should be supported by a complete curriculum implementation. In order to achieve the goal of holistic education, the designed curriculum should also be directed towards achieving the goal of holistic human formation. It includes forming learners into true learners who always think holistically and understand that everything is interrelated or related.

In developing the values of holistic education in schools, the contents of the designed curriculum are not only implemented in the classroom, but there is a need for holistic implementation of the curriculum in the explicit activities which are applied in extracurricular, as well as intracurricular, and self-development. The characteristics of the curriculum of holistic education are as follows: 1) the learning is directed so that students are aware of their uniqueness with all their potentials. They should be encouraged to connect with their inner selves, to make them understand the existence and authority, and at the same time, they rely everything entirely on The Creator, 2) the learning does not only develop analytical/linear way of thinking but also the intuitive, 3) the learning has an obligation to develop the potentials of multiple intelligences, 4) the learning has an obligation to awaken the students about their relationship with the community, so they should not ignore the traditions, culture, cooperation, human relations, and the fulfilment of appropriate needs (jawa: nrimo ing pandum, anti konsumerisme), and 5) the learning has an obligation to invite students to be aware of their relationship with the earth and non-human "societies" such as animals, plants and inanimate objects (water, air, soil) so that they have ecological awareness (Rubiyanto \& Haryanto, 2010).
These curriculum management activities are expected to have an impact on the development of students' potentials that includes cognitive (remembering, recognizing facts and logical thinking), affective (accepting, responding, judging, organizing, characterizing), and psychomotor (moving their limbs in coordination, imitating examples from others) (Seifert, 2007).

The curriculum is an instrumental school input that has a very significant contribution in determining the direction of potential development of learners. Learners' potentials will be able to grow intact when they are supported by a holistic school curriculum. Miller and Seller propose three curriculum orientations that shape metaorientation in curriculum planning, namely: transmission, transaction, and transformational (Musfah, 2012).

In the transmission orientation, the function of education is to inherit or transcribe the facts, values, and skill to the learners, or it can be said as the contents of the curriculum are transferred to the learners, so that the education is directed to subjects, and the learning is aimed to master the text book (subject orientation) using a conventional learning methodology. This kind of curriculum model is subject academic curriculum. Therefore, education is directed to master certain cultural values to live the life (basic skill-cultural transmission orientation).

The transaction orientation (transaction) explains that education is a dialogue between the participants and the curriculum. Learners are considered as individuals who have the ability to solve problems. It does not mean that learners do not have the potential and experience as stated in John Lock's tabular theory in which the transaction curriculum and learners influence each other. Thus, the transaction orientation of education emphasizes more on the problem solving learning (cognitive process orientation) through dialogue processes. 
While the transformational orientation, the educational process is aimed for the development of the personality to become a complete human being. Learners and curriculum unite, and then there is a process through this curriculum and later the transformation/change/development is formed. The educational theories used here are progressive and romantic education; while the curriculum model is a humanistic curriculum and transpersonal psychology that emphasize the level of ego (humanistic) and spiritual (transpersonal) fulfillment. Because the goal of education according to the transformation is an individual development (self-development), then the patterns of close relationship between individuals and society are the developed. To support the concept of transformation, various skills are taught as the vision of transformation in which a social change is a harmonious movement with the environment, including giving spiritual attributes to the environment. Therefore, the transformational considers that a successful education is self-actualizing education, or it can be said an education that can develop the emotional, intellectual, and spiritual character of learners.

Based on the three curriculum orientations above, the researcher can emphasize that the curriculum that is closer to the holistic education is the transformational curriculum, because holistic education is concerned with the needs and potentials of learners in terms of cognitive, emotional, social, spiritual, creativity, and physical. It is accordance with the vision of the transformational curriculum that is to develop the potentials and contextual learning. The learning in Muhammadiyah Schools is a transformational curriculum model, because it addresses the needs and potentials of learners in terms of cognitive, emotional, social, spiritual, creative, and physical. This transformational curriculum model is the one that supports the implementation of holistic education in schools.

Holistic learning practices include interdependence, interrelationship, participatory, and non-linearity. Interdependence means that each part is related to the function of the other part, thus forming a complete and whole system. Interrelationship means the existing system is a complex network, and there is a relationship with the external system. Participatory means that anyone involved in the learning will have a very close relationship with the existing learning environment. Nonlinearity means the holistic learning system is opened-ended, with complex interaction patterns, dynamic feedback systems, automatic self-organizing systems, and the connection is not linear instead dialectic (Zamroni, 2014).

Meanwhile, according to Miller et al (2005) in his writings Holistic Learning and Spirituality in Education: Breaking New Ground, there are three principles in the implementation of holistic education, namely connectedness, inclusion, and balance. Muhammad Thohir (Musfah, 2012) describes these three principles as follows: first, connectedness refers to the link between the curriculum framework and the various approaches used at each level of the learning. This connectivity includes the integration of analytical and intuitive thinking, between body and mind, the integration of teaching materials with society, as well as the synergy between soul and spirit. The principle of connectedness generally refers to how the curriculum framework is designed holistically, and specifically on the subject matter itself.

Second, is openness? This refers to what extent a diverse range of students may be involved in education, or in other words, to what extent the organizers provide the scope for anyone who wants to learn. This principle can be understood that there are no exceptions for children with special needs that they still have the right to learn. The organizers of holistic education should not discriminate between services for these children with the normal ones. Third is balance. This concept can be understood that it is not appropriate if an education is held orientating towards material needs only and ignoring other needs. 
On the contrary, the education only focuses on religious matters and neglect the world matter is not accordance with the third principle.

Holistic education cannot be separated in the unity of the whole dimension. These three principles are similar to Citting Kessler, Schiller Believes in Miller (2005) which says that: ... learning "cannot really be separated into cognitive, psychological, physiological, or spiritual". These four dimensions, cognitive, affective, psychomotor (physiological), and spiritual are a unity in a learning.

Holistic education in this context is to facilitate the development of children in all their dimensions completely and perfectly. Here, the holistic education aims to help learners become perfect, so that the primary school education is not only aimed to prepare learners to enter the next school level, but also to prepare them to live in the real world.

Implementation of holistic education in Muhammadiyah Sleman Elementary School has developed six human potentials, which are: first, cognitive potential. Theoretical constructs to develop cognitiveintellectual potential are through: a) active learning, b) using student-centered approaches, c) learning by discussion and question-answer methods, d) teachers do setting class and class conductivity, e) intertwining educational interactions of threeway pattern in learning, f) building interpersonal communication of teachers and learners outside the classroom, and $\mathrm{g}$ ) building psychological environment or social climate, intensive teachers and parents collaboration. The development of cognitiveintellectual potential is actually contained other potential development, because one aspect can be developed through other aspects.

Second, the aspects of emotional potential are focused on: a) self-confidence, b) sympathy, c) empathy, d) stress control, e) self-control from negative actions, and f) respecting others. Train the students' self- confidence by asking learners to convey the results of discussions or assignments in front of the class. The form of self-confidence in learners is not only evidenced by the activities that exist in the class, but also the involvement in the contest both in school and outside school. In the aspect of sympathy, through learning, learners tell about the social problems that exist in the community in order to involving the emotions of learners. Learners study outside the classroom, in order to determine the learning material being taught. One of the ways is through outing activities, in order to add insight and provide real-life experience to learners.

In empathy indicators, school always encourages learners to help victims of natural disasters, and ask learners to help when there are other learners in distressed. School awareness is not only shown to the victims of natural disasters who's outside the school, but also the concern is shown to learners or school residents who experience distress. In the indicator of self-control of negative deeds, schools facilitate extracurricular activities and tutoring, thus after school hours learners can fill their spare time with positive activities. Indicator on respect for others is reflected in school routine activities such as welcoming the students' arrival in the school's gate and shaking hands, being able to appreciate and accept the opinions of others by habitualize the method of question-answer and discussion in the learning process.

Third, the development of social potential aspect focused on indicators of a) awareness of social issues and social-spirited, b) responsible, c) comply with all applicable regulations, and d) work in team. A social awareness attitude in school is developed through school culture such as visiting school's member who is in distress, collecting donations for victims of natural disasters, and visiting sick people. This applies not only to learners but to the entire school community.

The value of responsibility to the learner is reflected from picking up and disposing garbage to its place, the habit of disposing garbage to its place is not only 
contained the value of physical hygiene, but also the moral message of love hygiene. Another form of responsibility is to do the task given by the teacher. The pattern of giving homework is still strong in Muhammadiyah Sleman Elementary School. It is because not all learners have the same ability to capture or understand the lessons that have been delivered by the teacher in the classroom, so that learners need more opportunities to learn. The positive value of homework is to train the personal responsibilities necessary to familiarize learning regularly and also to build partnerships between schools and parents so that it empowers the education.

Developing aspects of social potential to comply with all applicable regulations, school have rules and regulations for teachers and employees as well as for learners. Even for students, the school has rules and discipline in the school and classroom. While the rules for teachers and employees are legally-formal has been set in the Decree of the Branch Board of Muhammadiyah Sleman. Developing the social aspects potential of work in teams is learners get used to working in groups in the learning process, and implementing cooperative learning. In addition, through Hizbul Wathan (Muhammadiyah Scout) activities and camp activities.

Developing aspects of social potential in building a sense of affection is reflected in the ability of teachers to speak well with learners in the learning process and also in daily life in the school environment. In addition, the value of brotherhood and peace is developed through school activities by organizing social activities. Social conscience is in the context of social relationship (interpersonal) or benefiting others. In addition, schools often hold friendly match with other schools or attend the contest outside the school as a medium to strengthen friendship relationships between learners and other school students, or strengthen the institutional cooperation between schools.
Fourth, spiritual potential. This aspect of spiritual potential is focused on indicators of: 1) devout in praying; 2) behave in gratitude; and 3) pray before and after activities. Devout in praying for elementary students of Muhammadiyah Sleman Elementary School is supported by the application of religious culture in school. The adherence to pray is cultivated in Muhammadiyah Sleman Elementary School through the school program, such as the habituation of dhuha and zuhur pray in congregation in school, and reading and memorizing of Quran for students and teachers, animal sacrifice of qurban in school and distribution of zakat fitrah (charity given to the poor).

The attitude of accepting the assignment from the teacher with an open attitude is a form of learners' gratitude towards the school's work. Learners receive homework given by teachers openly and with pleasure. Learners feel not discouraged by the grade obtained. The development of spiritual attitudes can also be manifested in the form of praying before and after learning. It is cultivated every day and done in all classes as a manifestation of spirituality within the learners in learning.

Fifth, the potential of creativity. The development of creativity potential is reflected in the ability of learners to express themselves in productive activities. Selfexpression in productive activities is manifested in the ability of students to writing in order to fill the school's wall magazine. Potential creativity also reflected through intrakurikuler activities of potential creation and the students' work displayed in the classroom. Decorations and classroom wall decoration are displayed by students as a product of lessons of Art, Culture, and Skills or Art, Culture, and Practice.

Sixth, physical potential, including fine and gross motor is done through learning activities by inviting light gymnastics (ice breaking) in learning, and through extracurricular activities such as futsal, swimming, Tapak Suci/martial arts. While the 
development of fine motor potential is done through the development of intrakurikuler activities (lessons of Art, Culture, and Skills or Art, Culture, and Practice) and the potential creation of learners.

\section{CONCLUSION AND RECOMMENDATION}

Muhammadiyah Schools as a part of the National Education System as well as Islamic Education has mandated the implementation of holistic education. It means that all Muhammadiyah educational institutions carry the mission of implementing holistic education, which is an education model that develops all aspects of the human potentials of learners (cognitive, emotional, social, spiritual, creativity, and physical). Therefore, from the Muhammadiyah education, it is expected to produce holistic learners who are not only smart from the cognitive side, but also can develop other humanitarian potentials.

Holistic education in Muhammadiyah schools will produce human beings who are able to develop all their humanitarian potentials in a balanced way to assume the task of their leadership in establishing the hablum minaulah and hablum minannas relations as a result of the wholeness of the education process. Then, it is expected that students are good individually and socially.

The Muhammadiyah School as part of the National Education System as well as Islamic Education has mandated to the implementation of holistic education. It means that all Muhammadiyah educational institutions carry out the mission of implementing holistic education, which is an education model that develops all aspects of the human potential of learners (cognitive, emotional, social, spiritual, creativity, and physical), thus it is expected to be born from the womb of Muhammadiyah education the holistic learners, not only smart on the cognitive side, but also can develop other humanism potential.

\section{REFERENCES}

Ahmad, F. (2015). Pemikiran KH Ahmad Dahlan tentang pendidikan dan implementasinya di SMP Muhammadiyah 6 Yogyakarta tahun 2014/2015. Profetika Jurnal Studi Islam, 16(2), 144-154.

Ali, M. (2016). Membedah Tujuan Pendidikan Muhammadiyah. Profetika: Jurnal Studi Islam, 17(01), 43-56.

Amin, N. (2017). Menyemai Nasionalisme dari Spirit Agama: Upaya Meredam Radikalisme Beragama. Jurnal THEOLOGIA, 23(1), 109-123.

Amirudin, N. (2018). Humanism Education of Kiyai Haji Ahmad Dahlan (Tracing the Early Muhammadiyah Period of Education and Its Implications). Journal of Social Science Studies, 5(2), 171-182.

Azra, A. (2002). Islam Nusantara: Jaringan Global dan Lokal. Mizan.

Biesta, G. (2009). Good education in an age of measurement: On the need to reconnect with the question of purpose in education. Educational Assessment, Evaluation and Accountability (Formerly: Journal of Personnel Evaluation in Education), 21(1), 3346.

Burhani, A. N. (2005). The 45th Muhammadiyah Congress Contest between Literal-Conservative and Liberal-Moderate Muslims in Indonesia. Studia Islamika, 12(1).

Chaidar, A., \& Sahrasad, H. (2013). Negara, Islam, dan nasionalisme sebuah perspektif. Jurnal Kawistara, 3(1).

Embong, R., Din, N., Murshidah, N., Noruddin, N., Yaacob, A., \& Abu Bakar, N. (2015). A model of holistic personality based on transformative educational approach. 
Fuad, M. (2004). Islam, modernity and Muhammadiyah's educational Programme. Inter-Asia Cultural Studies, 5(3), 400-414.

Gallegos Nava, R. (2000). A multidimensional, multilevel perspective of holistic education. An integrated model. A presentation at the 8th holistic education conference, Guadalajara, Mexico.

Gunawan Suryoputro, G., Pudjo Sumedi, P., \& Muchdie, M. (2014). Riset dan Kajian Seabad Muhammadiyah. UHAMKA PRESS.

Hamami, T. (2011). Revitalisasi Pendidikan Muhammadiyah: Upaya Memadukan Cita-cita dan Kenyataan, dalam The Creating of Great School Spirit and Mindset. Yogyakarta: Majelis Dikdasmen PWM DIY.

Hassan, A., Suhid, A., Abiddin, N. Z., Ismail, H., \& Hussin, H. (2010). The role of Islamic philosophy of education in aspiring holistic learning. ProcediaSocial and Behavioral Sciences, 5, 2113-2118.

Heafford, M. R. (2016). Pestalozzi: His thought and its relevance today. Routledge.

Huda, M., \& Kartanegara, M. (2015). Ethical Foundation of Character Education in Indonesia: Reflections on Integration between Ahmad Dahlan and alZarnūjīi. International Conference of Malay Muslim Prominent Scholars. Selangor: Kolej Universiti Islam Antarbangsa (KUIS).

Jackson, E., \& Parker, L. (2008). "Enriched with Knowledge": Modernisation, Islamisation and the Future of Islamic Education in Indonesia. RIMA: Review of Indonesian and Malaysian Affairs, 42(1), 21.

Kim, H.-J. (2010). Praxis and Religious Authority in Islam: The Case of
Ahmad Dahlan, Founder of Muhammadiyah. Studia Islamika, 17(1).

Kuntoro, S. A. (2006). Menapak jejak pendidikan nasional Indonesia. Dalam Buku Kearifan Sang Profesor, Bersuku-Bangsa Untuk Saling Mengenal.

Lubis, M., \& Zubaedi. (2008). Evaluasi Pendidikan Nilai: Perkembangan Moral Keagamaan Mahasiswa PTAIN. Pustaka Pelajar.

Mason, M. (2008). Complexity theory and the philosophy of education. Educational Philosophy and Theory, 40(1), 4-18.

Masruri, M. H. (2009). Pendidikan menurut Ibnu Thufail (Perspektif Teori Taxonomy Bloom). Pendidikan Islam Dari Paradigma Klasik Hingga Kontemporer,(Malang: UIN Malang Press, 2009), Hlm, 187-213.

Mawardi, A. (2016). Studi Pemikiran Pendidikan KH. Ahmad Dahlan. TARBAWI: Jurnal Pendidikan Agama Islam, 1(2), 94-102.

Miller, J. P., Karsten, S., Denton, D., Orr, D., \& Kates, I. C. (2005). Holistic learning and spirituality in education: Breaking new ground. SUNY Press.

Mulkhan, A. M. (2010). Kiai Ahmad Dahlan: Jejak pembaruan sosial dan kemanusiaan: kado satu abad Muhammadiyah. Penerbit Buku Kompas.

Mundiri, A. (2016). Strategi Lembaga Pendidikan Islam Dalam Membangun Branding Image. PEDAGOGIK: JURNAL PENDIDIKAN, 3(2).

Murod, A. C. (2011). Nasionalisme" Dalam Pespektif Islam". Citra Lekha, 15(2), 45-58.

Musfah, J. (2012). Pendidikan holistik: Pendekatan lintas perspektif. Prenada Media. 
Nakamura, M. (2012). The Crescent Arises Over the Banyan Tree: A Study of the Muhammadiyah Movement in a Central Javanese Town, c. 1910-2010. Institute of Southeast Asian Studies.

Noddings, N. (2018). Philosophy of education. Routledge.

Nuryana, Z. (2017). Revitalisasi Pendidikan Al-Islam Dan Kemuhammadiyahan Pada Perguruan Muhammadiyah. TAMADDUN, 1-11.

Palahuddin, P. (2018). Modernisasi Pendidikan Islam di Indonesia Awal Abad Ke-XX: Kasus Muhammadiyah. SANGKéP: Jurnal Kajian Sosial Keagamaan, 1(1), 61-83.

Rubiyanto, N., \& Haryanto, D. (2010). Strategi pembelajaran holistik di sekolah. Jakarta: Prestasi Pustaka.

Santosa, N. E. T. I. (2012). Filsafat Pendidikan Muhammadiyah Akhir Zaman. Universitas Muhammadiyah Sidoarjo.

Seifert, K. (2007). Manajemen Pembelajaran dan Instruksi Pendidikan. Jogjakarta: IRCiSoD.

Setiawan, F. (2015). Geneologi dan Modernisasi Sistem Pendidikan Muhammadiyah 1911-1942. Yogyakarta: Semesta Ilmu.
Suprayogo, I. (2012). Pendidikan Holistik dalam Perspektif Islam. the A. Ghani and Riadi, Sugeng (ed), Pendidikan Holistik, Konsep dan ....

Surajudeen, A. T., Mat, M. Z. A., \& Alizadegani, F. (2017). An Exploratory Factor Analysis (EFA) in determining dimensions of integrated and holistic Islamic education among Kuliyyah of Education. O-JIE: Online Journal of Islamic Education, 3(1), 131.

Susilo, M. J. (2017). Leadership Model in Muhammadiyah to create independence school. Proceedings of International Symposium on the Transition from School to Work, 125131.

Syaifuddin, M. A., Anggraeni, H., Khotimah, P. C., \& Mahfud, C. (2019). Sejarah Sosial Pendidikan Islam Modern Di Muhammadiyah. TADARUS, 8(1).

Wahyudi, Y. (2006). Islam dan Nasionalisme. Yogyakarta: UIN Sunan Kalijaga.

Widyastono, H. (2012). Muatan Pendidikan Holistik Dalam Kurikulum Pendidikan Dasar Dan Menengah. Jurnal Pendidikan Dan Kebudayaan, 18(4), 467-476. 